\title{
KEPEMIMPINAN KEPALA SEKOLAH BERWAWASAN VISIONER-TRANSFORMATIF DALAM OTONOMI PENDIDIKAN
}

\section{Oleh: Rasmianto*}

\begin{abstract}
Kepernimpinan kepala sekolah mempunyai peran aktif dalam meningakatkan kualitas pendidikan sehingga ia diharuskan memiliki kemampuan leadership yang baik Sebab, kepemimpinan sekolah yang baik adalah yang mampu dan dapat mengelola semua sumber daya pendidikan untuk mencapai tujuan pendidikan baik dari sisi pembelajaran maupun pengembangan sumber daya manusia. Sehingga kepala sekolah juga dituntut untuk mampu menciptakan iklim organ isasi yang baik agar semua komponen sekolah dapat memerankan diri secara bersama untuk mencapai sasaran dan tujuan organisasi sekolah.
\end{abstract}

\section{Kata Kunci : Kepemimpinan, Kepala Sekolah, Transformatif, Otonomi Pendidikan}

\section{A. Pendahuluan}

Kompleksitas sekolah sebagai lembagapendidikan semakin berkembang seiring dengan tingkat perkembangan tuntutan lemabaga ini dari orang tua, siswa dan masyarakat luas. Faktor utama yang mendorong pentingnya meningkatan kualitas menejemen sekolah adalah untuk memperbaiki dan meningkatkan kualitas pendidikan, sehingga upaya perbaikan dalam pembelajaran dan pengajaran membutuhkan perhatian secara lebih baik, utamanya melalui meningkatkan kualitas menejemen (Bank Dunia, 1999). Di samping faktor guru, siswa, orang tua dan faktor lainnya untuk meningkatkan kualitas pendidikan di sekolah, maka faktor peran kepala sekolah juga tidak boleh diabaikan. Hal ini disebabkan sekolah sebagai suatu organisasi, maka peran seorang pimpinan menjadi bagian penting dari keefektifan lembaga dalam mencapai tujuan yang diharapkan. Kepala sekolah harus mampu untuk meningkatkan peran strategis dan teknis dalam meningkatkan kualitas pembelajaran dan pengajaran. Dia tidak saja sebagai pemimpin pembelajaran, tapi lebih dari itu adalah pemimpin secara keseluruahan yang mencakaup fungsi-fungsi kepemimpinan dalam suatu lembaga sekolah seperti perencanaan, pembinaan karir, koordinasi dan evaluasi.

Kepemimpinan adalah suatu upaya untuk mempengaruhi aktifitas individu atau kelompok secara sengaja untuk pencapaian tujuan organisasi (Stogdill, 1974; Yulk,

- Penulis adalah dosen Fakultas Tarbiyah dan juga sekretaris Unit Penerbitan UIIS Malang 
1989; Stoner, Freemen \& Gilbert, 1995; Owens, 1991; Hanson,1991; English, 1992). Sehingga dalam suatu organisasi kepemimpinan menjadi bagian penting dari upaya untuk menciptakan kinerja semua sumber daya untuk mencapai tujuan yang sudah ditetapkan. Sergivanni mengklasifikasikan kepemampuan kepemimpinan (dalam Owen, 1991)meliputi konseptual, humanistik, dan teknik. Sedangkan Owens(1992) menyebutkan ada dua tipe kepemimpinan kepala sekolah yaitu kepemimpinan simbolik dan kepemimpinan kultural. Selanjutnya Suyanto (2001) melihat bahwa kepala sekolah harus memiliki kepemimpinan transformatif untuk meningkatkan peran semua unsur sekolah secara optimal. Kemudian Guthrie dan Reed (1991), dengan mempertimbangkan komplekistas sekolah, dibutuhkan kepemimipinan strategis-visioner atau tranformatif. Lepas dari berbagai pendekatan ini, tapi yang lebih penting adalah tugas kepala sekolah menjadi bagian penting dari proses pendidikan di sekolah. Pembahasan ini akan membuat tulisan ini menarik yaitu menempatkan peran kepala sekolah sebagai aktor kebijakan dan perubahan di sekolah.

Kepemimpinan kepala sekolah sebagai agen perubahan dalam sekolah mempunyai peran aktif dalam meningakatkan kualitas pendidikan. Untuk meningkatkan kualitas pengelolaan sekolah maka kepala sekolah sebagai pimpinan harus mempunyai kemampuan leadership yang baik. Kepemimpinan yang baik adalah kepala sekolah yang mampu dan dapat mengelola semua sumber daya pendidikan untuk mencapai tujuan pendidikan. Kepala sekolah sebagai pemimpin pembelajaran dan sumber daya manusia (Mantja, 1995) hendaknya mampu menciptakan iklim organisasi yang baik agar semua komponen sekolah dapat memerankan diri secara bersama untuk mencapai sasaran dan tujuan organisasi. Itulah sebagai suatu alternatif kepemimpinan yang disebut kepemimpinan visionertransformatif. Dan bahkan yang lebih baru berkembang tentang kepemimpinan adalah pendekatan kemampuan emosional dalam kepemimpinan (Goleman, 1999; Goleman, 2001; Cooper, Robert \& Sawaf, 1999; Bennis \& Nanus, 1985).

\section{B. Konsep Dasar Kepemimpinan; Karekter dan Kerangka Teoritis}

\section{Pengertian Kepemimpinan}

Kepemimpinan merupakan prilaku untuk mempengaruhi individu atau kelompok untuk melakukan sesuatu dalam rangka tercapainya tujuan organisasi. Secara lebih sederhana dibedakan antara kepemimpinan dan menejemen, yaitu pemimpin mengerjakan suatu yang benar (people who do think right), sedangkan menejer mengerjakan suatu dengan benar (people do right think)(Bennis \& Nanus, 1985). Landasan inilah yang menjadi acuan mendasar untukmelihat peran pemimpin dalam suatu organisasi. Perbedaan ini memberikan gambaran bahwa pemimpin biasanya terkait dengan tingkat kebijakan puncak atau pengambil keputusan puncak yang 
bersifat menyeluruh dalam organisasi, sedangkan menejer merupakan pengambil keputusan tingkat menengah.

Dari sekian banyak pemahaman tentang kepemimpinan selalu menekankan pada aspek prilaku pemimpin dalam menciptakan pengaruh kepada yang dipimpin atau lebih dikenal dengan hubungan atasan dan bawahan. Dalam konsep-konsep kepemimpinan tradisional dan modem hal ini selalu menjadi tekanan utama. Sehingga lahir teori-toeri kepemimpinan yang selalu menjadikan dua arah tersebut sebagai faktor utamaunutk keefektifan kepemimpinan dalam suatu organisasi. Lihat misalnya teori bakat (trait thory), teori kontingency (contingency theory), teori phat goal (phat goal theory), yang lebih menekankan pada pembagian dimensi-dimensi kepemimpinan, yang tidak lepas dari dua aspek antara gaya dan prilaku kepemimpinan serta pengaruhnya terhadap keefektifan semua aktifitas organisasi, bahkan ada yang menekankan kepemimpinan pada upaya untuk menacapi tujuan organisasi, di mana bawahan diarahkan untuk melakukan tugas sebagiamana yang diberikan atasan.

Stooner, Freemen dan Gilbert (1995) memberikan batasan pada pemimpin pada tiga komponen mendasar, yaitu; pertama, kepemimpinan melibatkan orang lain, kedua, kepemimpinan melibatkan distribsi kekuasaan, ketiga, kepemimpinan adalah kemampuan menggunakan berbagai bentuk kekusaan untuk mempengaruhi orang lain atau pengikut, keemapat, kepemimpinan adalah mengenai nilai, karena mencakup semua sistem yang dapat menciptakan prilaku yang dipimpin. Bagian terakhir ini banyak dianut oleh pakar kepemimpinan sekarang ini, yaitu bagaimana menempatkan aspek manuisa sebagai aspek penting dalam suatu organisasi, yang bersifat interpersonal dan intrapersonal dapat mempengaruhi keefektifannya dalam melaksanakan tugas-tugas organisatoris.

\section{Pespektif Teori-Teori Kepemimpinan}

Teori kepemimpinan yang berkembang selama ini ingin mnegtahui bagaimana terjadinya keefektifan kepemimpinan dalam organisasi. Sehingga berbagai hasil pene;itian menemukan teori bahwa kepemimpinna dapat dilihat dari pribadi pemimpin, prilaku pemimpin, situasi budaya organisasi, hubungan pemimpin dengan yang dipimpin, hubungan pemimpin dengan tugas-tugasnya, dan seterusnya.

Ada beberapa teori kepemimpinan yang berkembang dalam yang selama ini dalam organisasi antara lain;

Pertama, Teori Sifat Tentang Kepemimpinan. Teori sifat menjelaskan bahwa kepemimpinan seorang sangat erat kaitannya dengan faktor sifat bawaan pribadi pemimpin sejak lahir. Teori ini juga disebut sebagai the "great man theory", yang merupakan sutau hasil studi otobiografi para pemimpin dunia seperti Gandhi, Roosvelt dan lain-lain oleh Thomas Carlyle (Hanson, 1991; Stooner, Freemen \& Gilbert, 1995). Dan pada awal tahun 1948 Ralph Stogdill mereveiu 124 penelitian 
pada bidang bakat psikologis dan menemukan bahwa faktor bakat itu kurang memiliki hubungan dengan keefektifan kepemimpinan. Atas dasar penelitian ini ia mampu untuk menjelaskan bakat-bakat psikologis seorang pemimpin meliputi; kemampuan, prestasi, tanggung jawab, partisipasi, status dan situasi (Hanson, 1991; Owens, 1991).

Mc Gregor (1960) pada tahun 1960 dengan bukunya "The Human Side Of Enterprise", menegasikan tentang bawaan individu merupakan faktor penentu keefektifan kepemimpinan. Lebih lanjut ia menjelaskan bahwa dalam kepemimpinan itu paling tidak ada empat variabel, yaitu: 1)karakteristik kepribadian pemimpin, 2)sikap, kebutuhan dan kepribadian para pengikutnya; 3)karaktersitik organisasinya, antara lain seperti: tujuan, struktur, sifat tugas yang harus dilaksanakan; dan 4) keadaan sosial, ekonomis, dan politis. Itulah sebanya ia menekankan bahwa kepeimpinan merupakan hubungan situasional dalam suatu oragnisasi.

Kedua, Teori Kontingency Tentang Kepemimpinan. Berbeda denga teori pendekatan sifat, bahwa teori kontengenci menyatakan situasi menentukan gaya kepemimpinan seorang pemimpin. Teori ini memfokuskan diri pada factor-faktor; tuntutan tugas, harapan dan tingkah laku rekan setingkat, karakter, harapan dan tingkah laku karyawan, dan budaya organisasi dan kebijakannnya. Salah satu dari teori ini adalah teori situasional kepemimpinan model Hersey and Blanchard (Owens, 1991; Hanson, 1991; Stooner, Freemen \& Gilbert, 1995). Teori situasional yaitu bagaimana gaya kepemimpinan sebagai respon terhadap keinginan sukses dalam suatu pekerjaan, pengalaman, kemauan, kemampuan bawahan yang juga harus mengalami perubahan.

Paul Hersey dan Kenneth Balanchard, seperti yang dijelaskan Owens (1991), mengemukakan bahwa teori kepemimpinan situasional meliputi; 1)tingkat kematangan partisipan organisasi dapat bertambah setiap waktu, 2) tingkat kematangan meningkat, maka gaya kepemimpian yang efektif akan dicirikan dengan reduksi prilaku yang berorientasi tugas dan meningkatkana prilaku berorentasi hubungan. Titik tekan dari gaya kepemimpinan adalah terletak pada faktor situasi hubungan tugas dan tanggung jawab dengan pencapian tujuan organisasi. Sehingga seorang pemimpin sering diarahkan dengan tujuan organsiasi dalam menentukan gaya kepemimpinannya. Hal inilah yang kemudian dikenal dengan menejemen berdasarkan tujuan (management by objective).

Ketiga, Teori Transformasional atau Harismatik. Teori ini merupakan teori yang relatif baru dalam ilmu menejemen, khsususnya tentang kepemimpinan dalam suatu organisasi. Teori ini lahir akibat diperlukannya tranformsi secara cepat dalam suatu organisasi yang didukung pengaruh besar seorang tokoh harismatis. Bernad M. Bass (dalam Stooner, Freemen \& Gilbert, 1995) membandingkan tipe pemimpin transaksional dan pemimpin transformasional. Pemimpin tarnsaksional menetapkan apa yang harus dialkukan oleh bawah untuk mencapai tujuan sendiri dan organisai. 
Sedangkan pemimpin tranformaional membangun motivasi bawahan untuk melakukan apa yang dibutuhkan oleh tim dan organisasi untuk mencapai tujuan aktualisasi diri anggotanya.

Kepemimpinan transaksional yaitu terjadinya hubungan antara atasan dan bawahan dalam agen bargening yang ditandai dengan prilaku individu dengan maksud tercapainya tujuan dan keinginan individu, dimana terjadinya hubungan timbal balik antara atasan dan bawahan. Sedangkan pimpinan transformasional bersifat visioner, memberikan nilai lalu diartikulasikan dan memberi inspirasi kepada para pengikut serta memberdayakannya yang diikuti dengan jalinan komunikasi secara aktif ( Tosi, Rizzo \& Carroal, 1990; White \& Bedner, 1991)

Teori tarnsformasional lebih mengutamakan pertisipasi aktif para anggota organisasi dalam mencapai tujaun organisasi. Anggota organisasi merupakan bagian penting dari roda organisasi. Sedangkan pemimpin diharapkn berperan dalam memberikan inspirasi dan membangun komunikasi secara efektif untuk menggerakkan kinerja anggota organisasi. Pemimpin menjadikan visi organisasi sebagai "perekat nilai" untuk membina sinergisitas anggota organisasi. Dimana seorang pemimpin berupaya menguatkan aspek motivasi anggota organisasi dengan menyatakan bahwa tujuan organisasi merupakan upaya untuk aktualisasi diri yang paling tinggi dalam tim kerja atau kelompok

Seperti yang ditulis Luthans $(1995 ; 358)$ (dalam Suyanto, 2001) mengkasisfikasikan seorang pemimpin yang sudah menerapkan kepemimpinan tranformasional yaitu: 1)mengindentifikasikan diri sebagai agen perubahan, 2)memilki sifat pemberani, 3)mempercayai orang lain, 4) bertindak atas dasar sistem nilai (bukan atas dasar kepentingan individu), 5) meningkatkan kepemimpinan secara terus-menerus, 6) memiliki kemampuan untuk menghadapi situasi yang rumit, tidak jelas, dan tidak menentu, 7)memiliki visi ke depan.

Keempat, Kepemimpinan Pendekatan Kecerdasan Emosional. Dalam pendekatan ini, bahwa kepemimpinan merupakan upaya untuk meyainkan orang lain untuk berkerja keras menuju sasaran bersama (Goleman, 2001). Kepemimpinan yaitu mempengaruhi dan menjalin hubungan dengan orang lain untuk mencapai tujuan (Buford \&Bedian, 1961; Stogdill, 1974; Owens, 1991). Sedangkan makna lain kepemimpinan yaitu kekuatan yang didasarkan atas karaktersitik personal, menyangkut kecerdasan emosional yang tinggi dan luhur (Etzoni, 1961, Cooper \& Sawaf, 1999) dalam berhubungandan berkomunikasi dengan orang lain pada organisasi untuk mencapai tujuan bersama.

Kepemipinan dengan pendekatan kecerdasan emosional merupakan kepemimpinan yang berdasarkan pada upaya maksimalisasi kemampuan interpersonal dan intrapersonal seorang pemimpin. Kemampuan interpersonal merupakan kemampuan untuk membangun hubungan sosial yang efektif dalam organisasi berupa mengelola kritik yang membangun, mengolala keragaman, 
mengelola kecerdasan kelompok (Goleman, 2001). Sedangkan kemampuan interpersonal merupakan kemampuan individual pemimpin dalam mengelola kepribadiannya untuk organisasi berupa kejujuran, integritas dan kepercayaan (Byrne dalam Bussiness Week, 2002).

Bennis (1984) mengungkapkan bahwa kepemimpinna yang efektif mempunyai beberapa kompentensi ayitu; 1) menejemen makna, pemimpin mampu memahami tujuan lembaga dan dapat mengelola simbol-simbol organisasi untuk tujuan, 2) perhatian, kemampuan pemimpin untuk mengajak para staf mengarahkan perhatian, tenaga serta bakatnya untuk mencapai tujuan lembaga, 3)menejemen kepercayaan, pemimpin beruapyan menumbuhkan kepercayaan orang lain, para stafnya, dan menerapkan gaya kepemimpinan kondisional, 4)menejemen diri sendiri, memahami dan mengenal dirinya. Dari ini dipahami bahwa kepemimpinan sangat erat kaitannya dengan karaketeristik personal peimpin (Hoy \&Miskel, 1987), yang merujuk pada aspek kepribadian dalam organisasi.

Kepemimpinan yang berdasarkan kecerdasan emosional merupakan pendekatan baru dalam ilmu menejemen (Goleman, 2001; Goleman, 1995;Cooper \&Sawaf, 1999). Daneil Goleman (1995) seorang ahli psikologi dari Harvard University, meluncurkan hasil sejumlah penelitian membuktikan pengaruh kecerdasan emosi seorang pemimpin untuk mencapai puncak karir. Ia menjelaskan ruang lingkup kecerdasan emosi yaitu kecakapan pribadi meliputi kesadaran diri, pengaturan diri, dan motivasi, dan kecakapan sosial meliputi empati, kesadaran terhadap perasaan, kebutuhan dan kepentingan orang lain, dan keterampilan sosial yaitu kepintaran dalam menggugah tanggapan yang dikehendaki orang lain (Goleman, 2001).

\section{Kepala Sekolah yang Visioner -Transformatif}

Kepala sekolah sebagai pimpinan lembaga pendidikan mempunyai peranan penting dalam rangka meningkatkan mutu pendidikan di sekoah. Paling tidak peran kepala sekolah melingkupi kepemimpinan personalia, kepemimpinan pembelajaran, dan kepemimpinan pembiayaan. Kepala sekolah diharapkan mempunyai peran utama dalam menciptakan kondisi organisasi agar tercapai tujuan dari sekolah secara optimal.

Liphm, Rankin dan Hoeh 1985) menjelaskan bahwa kepala sekolah harus membangun kepemimpinan atas dasar tujuan sekolah yang menjadi keyakinan dan prilaku semua komponen organisasi. Tujuan sekolah akan membangun fondasi dasar nilai yang akan dicapai lembaga sehinggga guru, murid, karyawan dan orang tua akan mencurahkan perhatian pada pencapaian tujuan organisasi tersebut. Lipham dkk. (1985) mengungkapkan tentang peran kepala sekolah, yaitu; menciptakan lingkungan sekolah sesuai dengan kondisi masyarakat sekitar, menghargai perbedaan individual yang terjadi di sekolah, kepala sekolah harus memformulasikan 
nilai dan tujuan yang diharapkan tercapai di sekolah, kepala sekolah harus berusaha untukmemahami nilai-nilai lain yang terjadi dalam interaksi interpersonal dan konflik peran, nilai-nilai tersebut berperan dalam menentukan nilai sekolah. Untuk itu kepala sekolah diharapkan dapat menciptakan tujuan sekolah sebagai pusat komitmen bagi semua komponen organisasi akan membantu tercapainya tujuan tersebut secara efektif dan efesien. Pemdekatan jenis ini lebih merupakan bagian dari proses manajemen berdasarkan tujuan organisasi, dimana bahwa tujuan yang akan memberikan pengaruh dominan pada setiap aktifitas organisasi.

Sedangkan Owens (1991) menekankan pada pentingnya kepemimpinan di sekolah untuk memperhatikan kepemimpinan simbolis dan kepemimpinan kultural sebagai upaya untuk mengelola budaya dan iklim sekolah. Pemimpin simbolis mengkomunikasikan visi sekolah kepada semua anggota organisasi, menjelaskan pentingnya peran senua organ organisasi untuk mencapai visi sekolah. Dalam kepemimpinan ini ditekankan agar seorang pemimpin dapat membangun semangat partisipasi yang tinggi pada semua komponen sekolah untuk meningkatkan kinerja dan sinergisitas organisasi dengan penekanan pada nilai apa yang penting untuk dilakukan para anggota. Lain halnya kepemimpinan kultural memberikan perhatian pada tujuan dan misi sekolah yang diartikulasikan dalam nilai, keyakinan, dan budaya sekolah. Dengan harapan dapat tertangun budaya dan iklim organisasi yangkondusif bagi kesehatan organisasi sekolah.

Di sini berarti betapa pentingnya upaya meningkatkan peran pemimpin dalam meningkatkan kualitas pengelolaan sekolah, yang akan memberikan dampak pada meningkatnya keefektifan tercapainya tujuan sekolah atau pembelajaran. Kepala sekolah, sebagaimana tugasnya dalam memimpin pembelajaran, harus mampu mengarahkan semua sumber daya pendidikan untuk mencapai tujuan pembelajaran di sekolah. Kepala sekolah diharapkan dapat membangun kultur organisasi yang profesional dengan meningkatkan kualitas guru, fasilitas, dan lingkungan sekolah yang mencerminkan sebuah lembaga pendidikan. Seorang pemimpin harus mengarahkan semua anggota sekolah agar merasa memiliki dan bertanggung jawab atas tercapainya tujuan sekolah. Semua komponen organisasi sekolah harus terlibat aktif dalam membangun sinergisitas organisatoris untuk mencapai tujuan organisasi.

Sedang kepemimpinan visioner-tranformatif merupakan kepemimpinan yang memberikan partisipasi guru, siswa, dan orang tua secara bersama-sama untuk memajukan sekolah. Seorang guru mungkin akan mempunyai kreatifitas sendiri dalam rangka meningkatkan kualitas pembelajaran di sekolah untuk memberikan berbagai upaya untuk mampu mengerahkan semua sumber daya pendidikan.

Berkaitan dengan fungsi kepala sekolah sebagai administrator pendidikan, pemimpin pendidikan dan supervisor pendidikan (Mantja, 2002). Kepala sekolah sebagai administrator pendidikan diharapkan dapat memberikan peran utama dalam rangka untuk menggunakan semua sumber daya pendidikan untuk mencapai tujuan 
organisasi. Sebagaimana diharapakan agar kepala sekolah melaksanakan fungsifungsi menejemen secara sistematis untuk mencapai tujuan pendidikan. Kepala sekolah sebagai pimpinan pendidikan agar berupaya optimal untuk meningkatkan kualitas dan keefektifan proses pendidikan di sekolah, utamanya yang berkaitan dengan prestasi siswa secara keseluruhan. Kepala sekolah sebagai pimpinan supervisi pendidikan hendaknya berusaha untuk meningkatkan profesionalisme guru dalam pembelajaran dan pengajaran. Bentuk upaya kepala sekolah dalam hal ini yaitu memberikan layanan supervisi untuk pembelajaran kepada semua guru untuk selalu memperbaiki dan meningkatkan kualitas pengajaran di sekolah.

Melihat perkembangan sekolah yang semakin kompleks, maka tugas kepala sekolah hendaknyamungkin tidak hanya sebagai seorang pemipmin pembelajaran (instructional leadership). Namun ia harus juga berupaya untuk mengelola sekolah dalam konteksnya yang lebih luas, yaitu sekolah sebagai tempat berlangsungnya proses pendidikan yang melibatkan banyak elemen masyarakat yang berkepentingan di dalamnya. Sehingga sekolah hendaknya mempunyai sistem menejemen yang baik untuk menunjang berlangsungnya proses tersebut dengan kondisi lingkungan yang menjamin pencapaian kualitas yang diharapkan.

Untuk itulah peran kepemimpinan kepala sekola akan mengarah pada mengelola aspek menejerial pendidikan yang berkaitan denga kesejahteraan guru dan karyawan, fasilitas pembejaran dan pendukung pendidikan lainnya. Dan yang tidak kalah pentingnya yaitu membangun hubungan dengan masyarakat, khususnya orang tua siswa untuk memberikan kesempatan untuk berpartisipasi dalam pengembangan pendidikan di sekolah. Ini artinya bahwa kepala sekolah harus mampu mengakomodasi semua pihak yang memungkinkan akan membantu atau mendukung bagi tercapainya kualitas pendidikan. Sehingga untuk mendukung hal tersebut , maka dibutuhkan tipe kepemimpinan visioner-tranformatif. Di mana bahwa kepala sekolah mampu membangun visi sekolah yang bewawasan pendidikan dengan memberikan keterlibatan semua komponen sekolah dalam mencapai visi organisasi yang diharapakan.

Lalu bagaimana karakteristik kepala sekolah yang visioner-transformatif itu? Kepala sekolah yang memimpin dengan gaya kepemimpinan visioner transformatif akan membangun organisasi yang berwawasan masa depan dengan landasan dasar pada artikulasi visi dan misi dalam budaya organisasi, budaya kerja dan iklim sekolah. Ia mampu untuk melakukan perubahan-perubahan edukatif ddalam rangka menuingkatkan kualitas pendididkan dengan mempertahankan prinsip dasar-prinsip dari pada pendidikan di sekolah.

Menurut Guthrien dan Reed bahwa seorang kepala sekolah yang tipe kepemimpinan visioner transformatif melakukan beberapa hal penting untuk mengelola sekolah, yaitu; (1)memahamai visi bagaimana sekolah akan berkembang lebih baik, (2) memahami bagaimana memotivasi mereka yang berkerja dalam 
sekolah seperti guru, karyawan, siswa dan orang tua, (3) memahami aspek-aspek operasional untuk mengontrol perubahan pada aktifitas organisasi, (4) menciptakan hubungan intensif dengan lingkungan onternal dan eksternal organisasi, (5) memahami komponen mendasar strategis pemikiran untuk membangun kultur organisasi yang baik (Guthrie dan Reed, 1991).

Untuk meningkatkan keefektifan dalam mengelola sekolah maka beberapa hal penting yang harus dimiliki kepala sekolah yaitu kemampuan politis (political competence), kemampuan pengajaran (instructional competence), kemampuan interpersonal (interpersonal competence) dan kemampuan teknis (technical competence)( Wiles dan Bondi, 1983). Kepala sekolah harus mamapu memberikan peran sebagai seorang insiator, inspiratosr, partisipator, dan motivator kepada guru, siswa, dan karyawan untuk sama-sama menciptakan sinergisitas untuk meningkatkan kienrja lemabaga dalam mencapai tujuan dan sasaran yang diharapkan.

\section{Daftar Rujukan}

English, W,F. 1992. Educational Administration: The Human Science: New York Harper Collins.

Hanson, Mark.E. 1991. Educational Adimistration and Organization Behavior: London. Allyen and Bacon.

Owens, Robert G. 1991. Onganizational Behavior In Educational: Toronto. Allyn and Becon.

Wiles, J and Bondi, J. 1983. Pricsiples On School Administration: The Real World Of Leadership in School: Columbus, Ohio: Bell and Howll Compony.

Liphmn, J, M, Rankin, R, E, dan Heoh, J,A. 1985. The Principalship: Concept, Copetenceis, and Cases. New York. Longman

Monahan,W,G, dan Hengst, R, Herbert. 1982. Contemporary Educational Administration. New York. Macmillan Publishing Co.Inc.

Manja, Willem, 2002. Manajemen Pendidikan dan Supervisi Pendidikan. Malang. Wineka Media.

Guthre, J. W, Reed, R, J. 1991. Educational Administration and Policy. Toronto. Allyn and Becon

Morgatroyd, S. dan Morgan, C. 1992. Total Quality Management and School: USA. The Open University.

Preedy,M.(Editor)1993. Manageing The Effecitve School: London. The Open University

Said, Chatlinas. 1988. Pengantar Administrasi Pendidikan. Jakarta. Depdikbud Sergiovanni.T.J. Burlingame, M. Coombs, F S, dan Thurstone, P. W,. 1992. Educational Governance and Administration. Tokyo. Allyn and Becon.

Stooner, F, Freemen, E, R dan Gilbert, D. 1998. Management: New Jerecy. Pretice Hall 